Philosophy and Progress: Vols. LVII-LVIII, January-June, July-December, 2015 ISSN 1607-2278 (Print), DOI : http://dx.doi.org/10.3329/pp.v57il-2.31208

\section{REVISITING THE NOTION OF 'ANALYSIS' ON THE BEDROCK OF ANALYTIC PHILOSOPHY}

\section{Sanjit Chakraborty*}

On 'Taking Sides in Philosophy’ (1937), Ryle opposes all sorts of 'ism' in philosophy. His ostensible revulsion attempts to see philosophy not as so-called party issues that depend on nonphilosophical prejudices. He thinks that two extremely different philosophical schools that have no agreement on their foundational claims sound unconvinced. During the period of the Second World War, the world not only bigoted two belligerent rivals; but regretfully philosophers (including Ryle himself) unsavourily engaged themselves to demarcate an edging line between the analytic and the continental. This division was portrayed from a historical, cultural, and geographical background and it strengthened the division between analytic and continental from the prospect of 'methodology'. The supporters show the clue from history of philosophy by bringing the contrast such as Eastern versus

\footnotetext{
* Ph.D. Scholar, Department of Philosophy, Jadavpur University, Kolkata-700032, India, E-mail : cogitosanjit@gmail.com
}

Western, Ancient versus Medieval versus Modern, Kantian versus Neo-Kantian and so on. Similarly, the division and the origin of analytic philosophy need to be considered as a hyped stage in the history of philosophy.

Philosophers, the question-minded beings in all eras, doubtlessly engage themselves in the quest of reasoning in the formulation of thoughts. A thinker guided by clarification, reason, impartiality, reflective thoughts, integrity and desire, and who assimilates new perspectives can be regarded as a philosopher. In his On What Matters (2011) Derek Parfit writes: "After learning from the works of great philosophers, we should try to make some more progress. By standing on the shoulders of giants, we may be able to see further than they could.” (p. 300) Therefore, one can query that the distinctive qualities are that what makes analytic philosophy promising and exclusive. The systematic inquiry raises qualm on the way that voids Anglo-American (analytic philosophy) with the continental (mainland Europe like Italy, France and Germany) one.

I think that analytic philosophy is a method of systematic thought that underpins the formation of language by eliminating the classical metaphysical system. It seems true that clarity and especially 'analysis' are the well-accepted equipments that analytic philosophers promoted. However, it seems to me that continental philosophy, mainly in German tradition, finds the prominent ideas of 'phenomenological analysis' in Edmund Husserl's thought and 'Ontological analysis' in Martin Heidegger’s writings correspondingly.

The specific feature of analytic philosophy intends to carry on a philosophical investigation from a subjective level. Various types of 'analyses' may rule over in philosophy at 
different time periods like scientific analysis in the period of logical positivism, logical analysis in the trend of FregeRussell, and decompositional analysis in Moore's hand. Analytic philosophy, just a hundred-year young philosophical trend, gets its standby introducing the first methodological approach that edifice language as a prime soul of philosophy. Analytic philosophers try to understand the 'linguistic representation' of the world from the ground of semantic (meaning) and reference. Another Copernican revolution that analytic philosophy persuades depends on the root of 'linguistic turn,' a turn that stresses on language to understand the world and the mind. Concentrating on mind and world one should see through language.

Frege, the father of analytic philosophy, concedes that the linguistic expressions have sense and reference together. The singular terms assign their reference by means of sense. The rudimentary approach that Frege appealed for analytic development is based on logical analysis that later goes toward semantic analysis. I think that "Frege has distinguished between the study of word-world relations (theory of reference) and the study of word-meaning relations (theory of sense). However, he wants to see them as working together in a fully integrated theory of language.” (Chakraborty, 2016, p. 11)

In 'On Denoting' Russell endures with the difficulty of meaning and reference taking into consideration Frege's stand on sense or reference, but apparently in a diverse way. Russell introduces the method of 'theory of descriptions' that Ramsey often called a "paradigm case of philosophy". Russell's criterion that relies on logical analysis sets out a distinction between names and definite description. Russell aims to rebuff the decomposition method of Moore by bringing the idea of logical analysis. An example of Russell's logical analysis is:
The present king of France is bald.

There is only one king of France, and whatever is king of France is bald.

In the case of analyzing the definite description, the concept of 'discompositionality' that Moore puts forward becomes inferior. For Russell, knowing an object means knowing only the description of the properties of the particular object. In the referred sentence 'the present king of France is bald,' here the whole sentence turns out to be meaningless because of the lack of meaning cum reference of the term 'present king of France'. Russellian singular terms construe the co-existence of the sense and referent. A genuine referring expression has some descriptive properties that relate to the referent, while pseudo or mock referring term lacks reference and it turns out meaningless. Undoubtedly, meaning takes a pertinent role in analytic philosophy. Simon Blackburn considers that the decisive facet of analytic philosophy stands on the groundwork of clarification and reference fixation (referent). Blackburn remarks: “A demonstrative needs a context to give it a reference: it can refer to different things on different occasions, and a competent user of the language will know this.” (1984, p. 303)

Wittgenstein, leading Cambridge analytic thinker, notices the pitfall of logical analysis and brings up the conception of conceptual analysis, as he considers that logically, independent elementary proposition remains unsteady. Analysis seems to him a brand that composes of presupposition, exclusion and implication. Ordinary language is beyond the calculus rules of logic and mathematics. Later Wittgenstein does not believe in the one to one relationship between words and objects. Wittgenstein's points emphasize 'everything lies open to view'. 
Therefore, his first challenge is that what language analysis attains is the conceptual variation of the logical structure of language, while another challenge goes toward the concepts of the world that is described by the contents of language.

Most philosophers consider that analytic philosophy in the Anglo-American field is more expanded in the hand of Wittgenstein. Wittgenstein structures language not as an expression of reality, but as a human practice or use, it is embedded in the 'form of life'. Wittgenstein says: "Languagegames are the forms of language with which a child begins to make use of words. The study of language-games is the study of primitive forms of language or primitive language.” (1958, p. 17)

Wittgenstein looks at meaning as use and explanation. Early Wittgenstein ponders the logical structure of 'picture theory' of language, but later, in Philosophical Investigations, he changed his mind by believing that language is a form of life and we participate in a game with language. Language in Wittgenstein's sense speaks about the world.

From 1930-1950, analytic philosophy was in deep influence of the logical positivists whom we called Vienna circle. They abet philosophy in two distinct approaches logical and conceptual (influenced by Wittgenstein). For them, the task of philosophy is to analyse the logical structure of language preserved by the conceptual scheme that lies behind it. Their visions were to unify science, use scientific knowledge in philosophy and introduce artificial language by promoting logic and mathematics. Empiricist credo on sensory evidence and natural science based justification, logical positivists not only applied in beliefs, but to language. A positivist refutes the genre of metaphysics and standoff the notion of verifiability hypothesis. These sorts of prospects talks about the second methodology of analytic philosophy that is familiar with the name of 'scientific spirit' in W.V Quine's sense. Early Quine was highly impressed by the logical positivists' thoughts. However, in 1951, the last nail Quine (1953, pp. 20-46) dragged in the coffin of logical positivism by arguing against the logical positivists' two foundational claims - the distinction between analytic and synthetic propositions and the conception of the reductive analysis. Actually, positivists believe in the procedure of meaning fixation of a confirming experience based statement from the aspect of 'stipulation'. The statements relating a priori truths are based on the stipulation or convention. So, analytic statements that are dependent on confirming experience become true just because of meaning alone. Quine mainly alludes and later refutes analyticity and $a$ priority in the sense of truth by convention.

Here one thing needs to be clarified is that 'analytic truth' that Quine purports to reject has a universal range of confirming experiences which relates to the concept of no matter what, a notion of a priority. It becomes redundant from the history of science, because there is no legitimate principle of science that believes in such a claim. The impetus that inspired Quine is undoubtedly the 'scientific spirit,' a second methodology of analytic philosophy, as I understand. In Mysticism and Logic (1925, p. 37), Russell stresses on the scientific philosophy. Quine most probably is the first philosopher who induces naturalism in epistemology by leaving out Aristotelian First Philosophy as vague and eloquently initiates a stance in favour of the scientific pursuit of truth. It seems clear to me that Quine's intention do not impose scientific burden on philosophy. However, his purpose was to eliminate dogmatic jargons from philosophy. Quine's 
'scientific spirit' outlines philosophy from the colours of evidential checkpoint, observation, naturalism, web of beliefs, holism, inter-subjectivity etc. Quine concedes meaning as a second grade notion and accepts the concept of 'stimulus meaning' for the cause of 'inter-subjective' communication in native language. Quine spells out later: "To learn a language is to learn the meaning of its sentences, and hence to learn what observations to count as evidence for and against them. The evidence relation and the semantical relation of observation to theory are co-extensive.” (1974, p. 38)

It sounds clear from the previous discussion that analysis, clarification and meaning, three major aspects allied to language, makes a good sense in analytic philosophy. J. L Austin, famous Oxford philosopher, originates a piecemeal procedure that Hilary Putnam and Quine refutes by introducing a holistic approach of the meaning of the sentence. Putnam considers that 'meanings' aren't objects. The dictionary meaning of a word can give us information, but that information does not determine the truth-evaluable content of a sentence in a context. He accepts that what sentences mean always depends on the connections to the world, and even in the case of logical or analytic sentences, the same rules are followed. That is not because of some supposed grand theses of 'meaning holism,' but because of the collapse of the unrelativized a priori. Putnam also strongly believes that the meaning of a single predicate depends on the entire sociolinguistic practices and the practices are related to the entire language, this thesis is regarded as semantic holism.

In Origins of Analytical Philosophy (1994), Michael Dummett significantly points out that the analysis of thought and language strictly escorts a differentiation between analytic and continental philosophy. One very interesting point that Ryle along with some continental philosophers raised against analytic philosophy is the disease of using havoc 'foot-and-end notes’. Hans Glock writes:

Indeed, Dummett published his aforementioned tome about Frege initially not just without footnotes, but also without a single quotation or reference. Once more, however, there is no absolute and pervasive contrast here between analytic philosophers and their non-analytic colleagues. When they write on historical issues, for example, analytic philosophers employ footnotes just as liberally as traditionalist philosophers, and quite properly so. Even outside such areas, what one might call the defensive footnote has become a notable feature of analytic writings. (2008, p. 167)

However, H.H Price in his seminal paper 'Clarity is not Enough' uses the term 'analytic philosophy' in 1945. He attacks the dogmatic process of clarity that any philosophical inquiry during the period gives immense importance. Even Rudolf Carnap also becomes agonized to see the basic orientation and the same style of thinking for the quest of clarity. The method of analysis takes a noteworthy position in analytic trend that we cannot evade anyhow. Some prominent thinkers agree on the question concerning the process and method of analytic philosophy, and they consider that here reason, clarity, scientific spirit, evidence and experience should underpin the analysis of language. Thomas Kuhn, a believer of scientific holism, rejects the idea of piecemeal procedure of analysis. Kuhn believes that both the scientists and common persons find out the world as whole from the instability of experience. In the case of child learning, it often follows that by using a term like 'mother,' a child not only learns who is his/her mother, but concurrently learns to pursue a differentiation of male and female. Kuhn writes that 'Paradigm determines large areas of experience at the same time.' (1970, p. 129) Kuhn thinks that 'paradigm' is a sharable scientific 
approach that is at the outset structured by community, not any way in isolation. The fashion tells us that language is neither empirical base nor a sociological event. Language belongs to the domain of scientific inquiry.

Hilary Putnam, a renaissance man of philosophy, clarifies that the vision of argumentative analysis of language is the core of analytic philosophy. Though semantic and logic pervades the conceptual analysis and logical analysis separately, yet we should open a genuine place for the scientific visions. In Putnam's Internal Realism: A linguistic Sketch of World" (2016a, pp. 179-188) I remarked:

In his 'internal realism', Putnam holds that reality has a human face because what is taken to be real is actually manmade i.e. it is related to the human point of view. Dummett also suggests that truth is related to cognitive activities and it is coming into existence through practice of language. It seems to me that for Putnam beliefs and concepts are human creations and therefore they relate to the world that is given in human experience and Putnam retains what he calls internal realism, which guarantees that our concepts are objectively true of the world and so must be taken as the objective feature of our conceptual scheme. I think that Putnam rejects the external realism because it considers the world as something independent of human mind.

The vast areas of analytic philosophy deploy different outlooks like linguistic, psychological, empirical, and scientific over the years. This line of thinking leads to safeguard language by setting a parameter of clarity in the notion of thought. Analytic philosophy tries to limit our human thought by concerning on the pyramid interrelation between language, thought and reality. Formal language philosophers like Russell, Frege, Carnap and logical positivists intend to construct an ideal language artificially. Such language will be free from any sort of unclarity, vagueness that assimilate in ordinary or natural language. An ideal language would be formal syntax and semantics based that nonetheless is derived from logical calculi. It also has one to one word and world corresponding logical vocabulary precisely guided by logical thoughts. Besides, the natural language is one that solely depends on grammar and social practices and has a productive and context based aspiration, which evades logical structure in the surface level of language that we call 'depth-structure'. It is well proven that if we construct any formal language, then minimally the base and the surface level of the language is constructed by natural language. Ideal language presupposes natural language. Natural language is unconstructed that is certainly a part of the history of human race. I think that the conception of the artificial language or ideal language can be an extension of natural language. Natural language can be logically ideal. We can realize more improvingly the logical structure of the common language. Davidson, Putnam and Hintikka derive the formal logical systems with the help of our regimented language. Besides, linguist like Noam Chomsky invents that the idea of universal grammar and innate base language faculty is demonstrated from our natural language. Language, even in Wittgenstein's sense, is a self-contained universal art, where everything that is described in words is imagined and included in language. However, Chomsky will suspect the mentioned aspect mainly because of his inclination towards 'Thought precedes language' hypothesis.

To precise the writing in a nutshell, I follow Dummett's staking doctrine that looks the maturity of philosophy from the coherence of logic and philosophy of language. The milestone of analytic philosophy begins from 1960 onwards from a recede to the approach of scientism. Philosophy in the hand of 
the analytic thinker becomes more humanistic endeavour rather than a snare of science. I think that the boundary line that we portrayed between analytic philosophy and continental philosophy become too shaky from the level of geographical background and visions. A lot of thinker who migrated or converted from the continental region later extremely nourished the development of analytic philosophy in AngloAmerican regions like Frege, Carnap, Wittgenstein and so on. Similarly, Charles Taylor, Hubert Dreyfus, Richard Rorty and Stanley Cavell are strongly inspired by continental thoughts and they make outstanding contributions in diversified areas. If we say that analysis, clarification, meaning and language are the founding pillars of analytic philosophy, and then we will see that continental philosophers like Gadamer, Husserl, Heidegger, Derrida, Isaiah Berlin, and Foucault have extensively worked in this realm. There are so many fields where analytic and continental philosophers exchange their thoughts and critique each other respectively. Some outstanding examples are as follows: Carnap's critique of Heidegger's The Nothing Nothings Hypothesis, Ryle's approach on Heidegger's Being and Time, Frege's letters to Husserl, Chomsky-Foucault Debate on Justice and Human Nature, Searle's and Derrida's Debate on Austin's Speech Act, Hilary Putnam and Habermas exchange of thoughts on the Fact/Value Dichotomy and so on.

There are many other examples that show the obsolete contrast between analytic and continental philosophy. There are so many interlinked areas where analytic and continental philosophers jointly and separately contributed, like in the areas of meaning, truth, intentionality, consciousness, mindworld relation, etc. The analytic trend that has grown-up in the hands of Frege, Wittgenstein, and Carnap and the trend that we called analytic philosophy now are not on the same page. There occurred a devastating change in the methods and visions of the later analytic thinkers. Similar thing happened in continental philosophy. Germany, France and Italy now like to see their philosophical trends from their own nationalistic stances and happily segregated into different schools. French philosophy moves from existentialism to social-political philosophy and post-modernism, whereas German tradition tries to get away from the jargon of phenomenology and interest in social-political theory, psychoanalysis, hermeneutics, empirical philosophy, pragmatism etc. My query is that what makes analytic philosophy still promising. I think that no one can deny the two revolutionary turns that analytic philosophy takes, which is obviously the linguistic turn (analysis of language and thought) and the naturalistic turn (metaphilosophical, epistemological, ontological naturalism). These turns kept alive analytic philosophy in its distinctive domain. It seems to me that engaging with profound thoughts and intellectual exercises have no boundary line. Philosophers are flying bird who does not know the horizon of the sky, but knows how to think and fly. More philosophically, Hilary Putnam says, "Philosophy is not only concerned with changing our views, but also with changing our sensibility, our ability to perceive and react to nuances.” (1999, p. 52)

\section{References}

1. Blackburn, Simon. (1984). Spreading the Words: Grounding in the Philosophy of Language, Oxford: Clarendon Press.

2. Chakraborty, Sanjit. (2016). Understanding Meaning and World: A Relook on Semantic Externalism, Newcastle, London: Cambridge Scholars Publishing.

\footnotetext{
* This paper is dedicated to the loving memory of my mentor Hilary Putnam (1926-2016), Emeritus Professor of Philosophy, Harvard University
} 
3. ---------. (2016a). 'Putnam's Internal Realism: A linguistic Sketch of World,' in Language, Mind and Reality, ed. Ranjan Kumar Panda, Florida: Brown Walker Press.

4. Dummett, Michael. (1994). Origins of Analytic Philosophy, Cambridge, Mass: Harvard University Press.

5. Glock, Hans-Jonathan. (2008). What Is Analytic Philosophy, Cambridge: Cambridge University Press.

6. Kuhn, Thomas. (1970). The Structure of Scientific Revolution, $2^{\text {nd }}$ ed., London, Chicago: University of Chicago Press.

7. Parfit, Derek. (2011). On What Matters, Volume One, edited and introduced by Samuel Scheffler, Oxford: Oxford University Press.

8. Putnam, Hilary. (1999). "Hilary Putnam: The Vision and Arguments of a famous Harvard Philosopher," in Key Philosophers in Conversation, ed. Andrew Pyle, London and New York: Routledge

9. Quine, W.V. (1953). "Two Dogmas of Empiricism,” in From a Logical Point of View, Cambridge, Mass: Harvard University Press.

10. ---------. (1974). The Roots of Reference, La Salle, Illinois: Open Court.

11. Russell, Bertrand. (1925). Mysticism and Logic, London: Longmans, Green \& Co.

12. Wittgenstein, Ludwig. (1958). The Blue and Brown Books, edited by Rush Rhees, Oxford: Basil Blackwell. 